\title{
Reflections Upon the Law of Political Parties
}

\section{Leonard M. Friedman*}

No one writes reflections any more. A bygone era treasured the essayist, the feuilletonist who held some aspect of life or law under scrutiny, discoursed lovingly for a few moments and then departed, making no point, driving home no argument and attempting no more than a brief illumination of his subject. Such writings are passé. And certainly they have scant place in a sober legal journal, which perforce derives a substantial part of its support from busy lawyers in search of bread-and-butter material.

Yet, in the matter of the law's impact on political parties there may be some occasion for a discussion of that sort. The legal profession, more than any other, has made American politics its own. Without benefit of statistics, it is probably true that during most of our national existence the majority of elective public offices in federal and state government have been held by lawyers. Too, lawyers have played a major role as party leaders and party workers. They were in the forefront of yesterday's local and state conventions, and they are prominent in today's central committees and party councils. Thus, it may not be amiss to consider some of the legal incidents of party existence and function, with the idea of developing concepts rather than specific rules of behavior.

"Political parties," one court has observed, are "neither mentioned, protected, nor favored in the Constitution." The prescience of the Founding Fathers fell short of recognizing the powerful role parties were to play in the new republic. For almost a century American constitutional and statutory law ignored the parties. What the law ignored it did not regulate.

The first American parties, Federalist and Republican, were hardly more than labels describing those who clustered around the opposing philosophies of Hamilton and Jefferson. They exercised none of the functions of party organization, fixed no membership criteria, nominated no candidates, erected no platforms. Candidates were nominated by caucuses, that is to say, by informal groups of influential gentlemen meeting in secret session. Samuel Adams' amusing description of the caucus antedates the Revolution. Yet it applies with equal vigor to the political forces which held sway in the early days of the republic: ${ }^{2}$

This day learned that the Caucus Club meets at certain times in the garret of Tom Dawes, the Adjutant of the Boston Regulars. He has a large house

* Deputy Attorney General, State of California. Views expressed in this article are those of the writer and should not be attributed to the California Department of Justice.

${ }^{1}$ State ex rel. Shepard v. Sup'r Ct., 60 Wasll. 370, 382, 111 Pac. 233, 238 (1910).

2 Quoted in Bone, ANrerican Politrcs ANd THE ParTy System 507 (1949). 
... and the whole club meets in one room. There they smoke tobacco till you cannot see from one end of the garret to the other. There they drink flip I suppose and they choose a moderator who puts questions to the vote regularly; and selectmen, assessors, collectors, firewards, and representatives are regularly chosen before they are chosen in town ....

In the age of Jackson caucus gave way to convention. The hierarchy of delegate conventions, local, state and national, was attended by a corresponding structure of local, state and national committees and subcommittees. Now the parties had achieved functional maturity. Now they constituted systemized entities, designed to capture and control the course of government through the election of their own adherents. Now they formed an extra-governmental, extra-legal complex of powers, exerting immense influence on government and law, yet unacknowledged by either.

These vital organs of the body politic possessed no more juridical status than a parlor debate club. From the political anatomist's viewpoint this was a paradox. From the standpoint of the lawyer it was quite understandable. In the absence of common law antecedents or statutory controls, the courts felt no need to characterize these prime forces as anything but "voluntary associations." 3 In that character, the parties exercised unqualified dominion over political functions-fixing membership criteria, nominating candidates for public office, conducting their campaigns and shaping their platforms.

Abuse of the convention system stimulated rudimentary but gradually strengthening statutory controls. As early as 1866 California adopted the Porter Law, providing an optional primary election which any "voluntary political association or party" might utilize for electing delegates or candidates. ${ }^{4}$ During the eighties and nineties the prevalence of ballot frauds led many states to adopt the Australian ballot system. Publicly-printed ballots now contained the names of candidates put forward by the parties. It became necessary that state laws define those parties which were qualified to nominate candidates and fix criteria by which election officials could recognize their nominees. This circumstance led to statutory definitions of "party," usually in terms of an aggregation which had polled a described vote at the preceding election or which had qualified by petition.

Thus was laid the statutory foundation for recognition of the parties as legal entities. California's Australian ballot law of 1891 was sustained in $1892 .^{5}$ For a while the Cahfornia Supreme Court resisted full recognition of the parties, holding that "political parties are a law unto themselves as

3 See 29 C.J.S., Elections $\$ 84$ (1941); dissent of Mr. Justice McReynolds in Nixon v. Condon, 286 U.S. 73, 89 (1932).

4 Cal. Stat. 1865-1866, c. 359, §§ 1-7.

5 Eaton v. Brown, 96 Cal. 371,31 Pac. 250 (1892). 
to the conduct of primary elections." ${ }^{\circ}$ Only a few years later a unanimous supreme court embraced the inevitable, declaring: ${ }^{7}$

The conception that a political party is merely a private association of citizens ... has . . . been very generally abandoned .... The state has seen fit to declare that political parties shall be as to their mode of holding conventions and nominating candidates for public office, regarded as public bodies whose methods are to be controlled by the state.

The following year it held that a political party may sue in its own name. ${ }^{8}$ The California judicial pendulum did not stop at acceptance of the parties as juridical entities. It swung farther, to the point of endowing these entities with "constitutional rights" immune from legislative impairment. The 1897 Legislature had adopted a mandatory primary election statute. It was quickly invalidated as an interference with suffrage. ${ }^{9}$ The 1899 Legislature tried again. A year later the second attempt was nullified by a split court. ${ }^{10}$ As spokesman for the majority, Mr. Justice Henshaw held that the absence of a party test for voters desiring to participate in party primaries was an unwarranted invasion of the rights of political parties. He did not trace these rights to constitutional protections possessed by the individual members of the party. These rights, as he envisioned them, rested upon extra-constitutional limitations drawn from "reserved rights" which the legislature could not impair. He quoted with approval from a Colorado case which declared: "Self-preservation is an inherent right of political parties as well as of individuals."11

That political parties have many inherent functions, which they exercise in the absence of statutory regulation, is a historical fact. ${ }^{12}$ It does not follow that they have inherent rights which fortify them against deprivation of these functions. Mr. Justice Henshaw's inherent rights concept was to receive further elaboration. A Political Code provision prevented fusion candidacies by prohibiting any candidate from running as the nominee of more than one party. Again, a split court invalidated the law. ${ }^{13} \mathrm{Mr}$. Justice Henshaw stated that the Australian ballot system had recognized the parties as legal entities. The prohibition of dual candidacy, he held, was a drastic interference with the right of a party to nominate whomsoever it pleased, regardless that another party had nominated the same person. $\mathrm{He}$

6 People v. Cavanaugh, 112 Cal. 674, 676, 44 Pac. 1057, 1058 (1896).

7 Katz v. Fitzgerald, 152 Cal. 433, 435, 93 Pac. 112, 113 (1907).

8 Independence League v. Taylor, 154 Cal. 179, 97 Pac. 303 (1908); see also Communist Party v. Peek, 20 Cal.2d 536, 127 P.2d 889 (1942).

- Spier v. Baker, 120 Cal. 370, 52 Pac. 659 (1898).

10 Britton v. Board of Commrs., 129 Cal. 337, 61 Pac. 1115 (1900).

11 Whipple v. Board, 25 Colo. 407, 420, 55 Pac. 172, 177 (1898).

12 See Star, The Legal Statzis of American Political Parties, I, 34 Axr. Poc. Scr. Rev. 439, 447-48 (1940).

13 Murphy v. Curry, 137 Cal. 479, 70 Pac. 461 (1902). 
might have rested the matter upon the law's interference with the prerogatives of the individual citizens affiliated with the party. He might have aimed his decision at the law's impact upon the nominee himself. Instead, he chose to express the problem as one which concerned a collective political creature, possessed of rights emanating from some unnamed, undescribed source. ${ }^{14}$

These decisions, of course, represented judicial legislation, or constitution-making, with a vengeance. The California concept of a political party as an entity endowed with independent constitutional protections was roundly criticized as a "false theory." 15 The basic objective of a direct primary system is the curtailment of the functions and powers of political parties. So long as these functions and powers had real or supposed constitutional protection in California, a compulsory primary system was a theoretical and practical impossibility. In 1908 the electors approved an amendment to article II, section $2 \mathrm{I} / 2$, of the California Constitution, empowering the legislature to enact compulsory primary election legislation. If such a system curtailed party "rights," the matter had now been taken out of the hands of the courts. Mr. Justice Henshaw's notion had become a ghostly abstraction which was silently laid to rest in 1942. In Communist Party v. Peek ${ }^{16}$ a unamimous court invalidated an exclusionary statute directed against a political party, not for its impact upon the party itself, but because it accomplished the primary election disfranchisement of the individual voters affiliated with the party.

As a matter of logic the Communist Party v. Peek approach is vastly more palatable than Mr. Justice Henshaw's. Conceivably, it may be more effective. If the parties are neither protected nor favored by guarantees of due process and equal protection, these bulwarks are available to the citizens who express themselves through the party. Its members, rather than the entity, become the conduit for assertion of constitutional protections. Artificial entities inay not be deprived of property without due process, but only natural persons have "liberty" which is entitled to protection under

14 The old quarrel over fusion candidates is strongly reminiscent of current controversies over cross-filing. In Hutchinson v. Brown, 122 Cal. 189, 192, 54 Pac. 738, 739 (1898), the court had declared ". . there is nothing unlawful in fusion." The anti-fusion statute denounced in Murphy v. Curry, $137 \mathrm{Cal}$. 479, 70 Pac. 461 (1902), was probably enacted in answer to the Hutchirson case. California's first successful compulsory primary law, that of 1909, expressly forbade two-party candidacies. This prohibition was sustained in Socialist Party v. Uhl, 155 Cal. 776, 103 Pac. 181 (1909). The 1913 law distinctly permitted cross-filing and this permission was likewise upheld. Hart v. Jordan, 168 Cal. 321, 143 Pac. 537 (1914). California's present fusion habits, as manifested by the cross-filing system, have been unsuccessfully attacked on federal constitutional grounds. Shaffer v. Jordan, 213 F.2d 393 (9th Cir. 1954); cf. Comment, 38 CAITF. L. Rev. 478, 480 n.10 (1950).

15 State ex rel. Shepard v. Sup'r Ct., 60 Wash. 370, 111 Pac. 233 (1910).

1620 Cal.2d 536, 127 P.2d 889 (1942). See also Independent Etc. Party v. County Clerks, 31 Cal.2d 549, 191 P.2d 6 (1948). 
the due process clause ${ }^{17}$ and only natural persons are entitled to the privileges and immunities which the 14th amendment secures to citizens of the United States. ${ }^{18}$ Thus, the areas of constitutional protection are seemingly broader when the party postulates "rights" indirectly, through the constitutional protections possessed by its members.

Endowed with rights or not, the California parties as representative organizations have been pushed out of much of their original domain. Their basic function of nominating candidates was virtually eliminated by the direct primary system. Party central committees are left with the vestigial task of filling ballot vacancies caused by the death or disqualification of nominated candidates and with the honorary mission of naming presidential electors. ${ }^{19}$ A second basic activity, establishment of membership criteria, has been replaced by the voter's individual declaration of affiliation. The voter's sworn avowal is the "best and only" evidence of party memberslip. ${ }^{20}$ A third task, formulation of party platforms, remains nominally untouched. But candidates nominated by the voters owe little allegiance to party platforms. The direct primary, plus cross-filing and a well-nigh universal inattention to state party platforms, have sapped this function of real significance. In statutory contemplation California party organs have been left with one major role - to campaign for the general election success of the party nominees selected by the voters at the primary. This role, according to statutory theory, they perform under direction of the state and county central committees. ${ }^{21}$

The evolution of parties from voluntary associations to quasi-official entities reveals a certain ambivalence. The legislative controls spawned by the reform wave of the past half-century have been directed mostly at the external manifestations of party conduct. There has been comparative laissez faire in the matter of internal relationships. Aside from laws decreeing the composition of the official party committees, internal structure and internal lines of authority have been left largely to natural processes. Shifts of power from one faction to another are accomplislied through compact, conflict, and compromise, without benefit of legislative or judicial interference. Asked to adjudicate the vahidity of internal party proceedings, Mr. Justice Garoutte of the California Supreme Court greeted the request with disdain: ${ }^{22}$

In the trial of such a question Blackstone and Kent would be entirely displaced by Cushing or Roberts. That character of investigation had better

\footnotetext{
17 Western Turf Association v. Greenberg, 204 U.S. 359, 363 (1907).

18 Hague v. C.I.O., 307 U.S. 496, 514 (1939).

19 CAL. Elec. CODE $\$ \S 2810,2894$.

20 Heney v. Jordan, 179 Cal. 24, 29, 175 Pac. 402, 404 (1918).

21 CAL, ELEC. CODE $\$ \S 2829,2831$.

22 McDonald v. Hinton, $114 \mathrm{Cal}$ 484, 489, 46 Pac. 870, 871-72 (1896); see Annots., 20 A.L.R. 1035 (1922), 169 A.L.R. 1281 (1947).
} 
come for consideration before a high school debating society rather than a court of last resort.

Absence of governmental concern with internal party affairs was bound to encourage political rebellion. In 1898 the People's Party convention joined with the Democrats and Silver Republicans in nominating a fusion slate, much to the dismay of the party regulars, who withdrew and nominated a simon-pure Populist slate. Notwithstanding the orthodoxy of the anti-fusion delegates, the state supreme court held that their ticket was not entitled to a place on the ballot. What did it matter if the convention liad overthrown the expectations of its constituents?

Delegates to political conventions are no doubt trustees in a large sense of the word, but they discharge a trust with which the courts do not meddle. They obey or disobey instructions as they see fit, and the only remedy for their disobedience is the censure of the people expressed at the polls. ${ }^{23}$

The 1912 state Republican Convention repudiated the nominees of the Republican National Convention and named a set of presidential electors pledged to the Progressive candidate, Theodore Roosevelt. Again, the supreme court refused to hear the plea of the party regulars. ${ }^{24}$ Only recently lave the county central committees received statutory authority to discipline bolting members. ${ }^{25}$

Considering the extent of statutory emasculation, a legal theoretician might view the parties as comparative impotents. That is not quite the case. Detailed statutory control of the official state and county committees lias stimulated a proliferation of unofficial party organizations in the form of assemblies, federations, councils and political clubs. Possessing more freedom and flexibility than the official committees, these unofficial conclaves usually command more campaign money and hence a more powerful voice in party affairs. Having no power to nominate, they influence the nominating process through endorsements and campaign contributions. Having no authority to impose party tests, they substitute persuasion of the voters registered with the party. Unable to formulate an official platform, they exert pressure on elected candidates who veer from party principles. These party assemblies, clubs and citizens' committees germinate and wither with each campaign. They form an extra-hierarchal, fluctuating set of organisms, depriving the parties of real form, tending toward fragmentation of control but also perpetuating a diffusion of program and strength. ${ }^{26}$ They

${ }^{23}$ Hutchinson v. Brown, 122 Cal. 189, 192, 54 Pac. 738, 739 (1898); see also Spelling v. Brown, 122 Cal. 277, 55 Pac. 126 (1898).

${ }^{24}$ Sbarboro v. Jordan, 164 Cal. 51, 127 Pac. 170 (1912).

25 See 7 Ops. Cax. Atr'y. Gen. 347 (1946); Cal. Elec. Code $\$ 2828$, as amended by Cal. Stat. 1951, c. 1408, \&2.

${ }^{26}$ See Farreity and Hinderaker, The Politics of CalfFornia 86-98 (1951); Harris, Caurfornia Poltrics 27-36 (1955); Marx, Legislation, Representation, and the Party System, 14 U. Prtr. L. Rev. 151 (1953); cf. Turner, Responsible Parties: A Dissent from the Floor, 45 Aar. Por. Scr. Rev. 143 (1951). 
represent the parties' adaptation to the stringencies of legal regulation.

Even the statutory central committees have a hife of their own. They form a natural medium of communication among the unofficial party groups. They are constricted only to the extent that they are regulated. When the fetters of regulation prove too irksome, they take off their official hats and forgather with their unofficial brethren. The state Attorney General has advised that the statutory state and county central committes may not endorse or campaign for competing candidates before the priniary. ${ }^{27}$ This prohibition, he reasons, stems from the committees' duty to campaign for the entire party in the general election campaign, a duty which bars them from backing part of the party in the prinary. Some of the committees reject this ruling. Others accept it and throw the pre-primary activities into the hands of the non-official groups. A recent spate of special legislative elections (where the primary election system does not obtain) has revealed the absence of any statutory definition of the committees' role in such campaigns. Some of the committees have endorsed special election candidates; others have not. The sheer impracticability of judicial attack on an accomplished endorsement contributes to the state of uncertainty.

Viewed apart from their historical genesis, laws governing the California parties present an illogical, disordered pattern. They preserve a state convention stripped of meaningful function. They erect detailed schemes for the selection of central committees but ignore the real centers of political power. They contemplate structure in the face of a protean formlessness. The vital factor in this amorphous statutory growth has not been logic, not even experience, but a series of extemporizations designed to meet the exigencies of particular occasions.

This is not to say that a thorough overhaul of the statutes is an immediate order of business. Perhaps definition and categorization are not matters of pressing import. To acknowledge the indispensability of strong, responsive parties in a democracy is to recognize that parties feed on responsibility and function. The reforin legislation of the past half-century curtailed their role and might well have reduced thein to a state of debility. The great problem in the field of election law is to balance the need for a vigorous party system against the desiderata of popular self-government. Current debates over cross-filing and "nonpartisanship" are expressions of this balancing process. The essential task is not to envision legal forms, nor to calculate the extent and type of regnlation, but to make a correct evaluation of party function. Legal forms and legal controls must shape themselves around that evaluation.

2719 Ops. CaI. Atr'y. Gen. 12 (1952) ; 23 Ops. CaI. Atr'y. Gen. 119 (1954). 